\title{
Masked Noncognate Priming across Farsi and English
}

\author{
Zahra Fotovatnia \\ Department of English, Najafabad Branch, Islamic Azad University, Najafabad, Iran \\ Email: Z_fotovatnia@phu.iaun.ac.ir \\ Ferdos Taleb \\ Department of English, Najafabad Branch, Islamic Azad University, Najafabad, Iran \\ Email: Ferdos_taleb@yahoo.com
}

\begin{abstract}
In an attempt to test the prediction made by dual lexical model (Gollan, Forster, \& Frost, 1997)regarding mental representation of non-cognate translation pairs (semantically similar translations) across languages with different scripts, non-cognate translation pairs were examined in a masked priming experiment across Farsi and English in L1-L2 and L2-L1direction. The results of the study showed a different pattern of priming for non-cognate as compared with Gollan et al study. The results of the study are discussed in terms of "entry opening "(Forster \& Davis 1984; Davis, Schoknecht, \& Carter, 1987) and Distributed Feature Model (De Groot ,1992).
\end{abstract}

Index Terms - masked priming, lexical decision task, prime, target

\section{INTRODUCTION}

One of the aims of bilingual studies is to discover the nature of bilingual lexical access and connections between the lexical systems of a bilingual. Targeting at discovering such connections, a number of studies have suggested some models for how the lexical systems of bilinguals are separated at lexical level yet interconnected at a conceptual level. Most of experimental studies done have theorized that bilinguals' languages are represented separately at the level of lexical form while connected at a conceptual level. Compound bilingualism and the concept mediation model are two such models (Weinreich 1953; Potter, So, Von Eckardt, \& Feldman, 1984; Kroll \& Curley, 1988; Chen \& Ng, 1989). According to these two models, two lexical systems are directly connected to a common conceptual system. Assuming the same or overlapping semantic representations for the two lexical representations of a bilingual; some interactions might be expected between two languages during word recognition and processing.

Different studies have adopted different techniques and a wide range of paradigms to assess the sort of interaction between L1 and L2 (de Groot,1992; Smith,1991,de Groot \& Nas,1991; Kroll \& Stewart,1994; Macleod,1976; Schwanenflugel \& Rey,1986). A number of studies have used cross language priming as an experimental technique to assess the nature of these connections (keatley \& de gelder, 1992; keatley, spink, \& de gelder, 1994). Regarding this technique adopted to investigate bilingual lexical organization, some authors believe that when the bilingual nature of the task is apparent, information about the prime may reach consciousness so that any observed priming effects can be a result of non-automatic or strategic processing rather than reflecting automatic processing mechanism per se by which it is meant that bilinguals strategically connect one language with the other by detecting the relationship between the prime and the target stimulus(Kirsner, Smith, Lockhart, King, and Jain 1984)

A way to hide the bilingual nature of the task is the use of an experimental technique called masked priming paradigm developed recently in studies of visual word recognition (e.g., Evett \& Humphreys, 1981; Forster \& Davis, 1984) by use of which prime cannot be identified. In this paradigm, a very briefly presented prime preceded by a forward mask (like a number of signs) is immediately followed by a given target stimulus. Due to adopted masking procedure, the prime is, for most subjects, virtually invisible and it can not be identified.

Having adopted masked priming paradigm, some empirical studies focused on cognate non-cognate difference. Noncognates are translation equivalents with different spelling and sound pattern in the two languages (e.g., the Farsi word $a b i$ and its English translation blue), whereas cognates are translation equivalents with the same origin and usually similar semantic, phonological and orthographical properties across languages (e.g., the Farsi word lab and its English translation lip). These studies have often compared the magnitude of priming for cognates with non-cognates (Chen \& Ng, 1989; Cristoffanini, Kirsner, \& Milech, 1986; de Groot \& Nas, 1991; Gollan, Forster, \&Frost, 1997; Keatley\&de Gelder, 1992; Williams, 1994). In fact, these studies have explored whether a significant effect could be found for words that share semantic, orthographical and phonological representations (cognates) under masked priming condition in comparison with words that only share semantic representation (non-cognates).

Studies using very short prime exposures and masked priming paradigm have obtained systematic facilitation from cognate translation primes however, the results concerning non-cognate translation equivalents are somewhat mixed(de 
Groot \& Nas, 1991; Gollanet al., 1997; Sanchez-Casas, Davis, \& Garcia-Albea, 1992; Williams, 1994). In the study of de groot and Nas (1991), priming obtained for non-cognate translation pairs were systematically smaller in comparison with effects observed for cognates in the lexical decision task. In another study by Sanchez-Casas et al. (1992), only cognate pairs showed significant priming in a semantic categorization task. On the basis of these results, de Groot and Nas and Sanchez-Casas et al. suggested that cognate translations may share common representations in memory whereas non-cognate translation equivalents do not.

Assuming that cognates share the same representations in memory, a number of studies focused on the role of orthography in establishing shared lexical entries for cognates in bilinguals' memory. They investigated whether both orthographic and phonological overlaps are required for establishing such entries or orthography does not have any role in this process.

In an attempt to test languages with different scripts, Bowers, Mimouni, and Arguin (2000) failed to find any priming for Arabic/English whereas significant priming was obtained for orthographically similar languages. Therefore it was concluded that orthography plays a role in obtaining cognate effect. In another study by Gollan et al (1997), four experiments were designed to examine the necessity of orthographical overlap in obtaining significant cognate effect. Both cognates and non-cognates were included in the experiments for the purpose of comparison. The results of the study showed that in contrast with Bower et al's study (2000), despite the absence of orthographical overlap, enhanced cognate priming was observed. One noticeable finding of this study was that unlike previous studies, priming was also obtained for non-cognates. The results of the study were interpreted in terms of a dual lexical model according to which "script differences facilitate rapid access by providing a cue to the lexical processor that directs access to the proper lexicon, thus producing stable non-cognate priming"(p 1122 ). Hence Golan et al. (1997) suggest that it was their use of languages with different scripts (i.e. Hebrew and English) that allowed significant effects of non-cognate translation primes to emerge.

However, Williams (1994) having obtained such an effect in another study using masked prime paradigm and the lexical decision task indicated that this is not a necessary condition, as he obtained significant non-cognate translation priming with Italian-English, French-English and German- English bilinguals. As the results obtained for non-cognates across different experiments are mixed, further research is required to clarify this critical issue.

The main aim of this study is to investigate whether or not non-cognates across languages with different scripts co activate each other under masked priming conditions. This study helps to evaluate the dual lexical model put forward by Golan et al. (1997). The main question to be answered in the present study is:

- Is there any non-cognate priming effect for Farsi-English bilinguals in L1-L2 or L2-L1 direction?

\section{METHOD}

\section{A. Experiment 1- L1-L2 Priming}

The purpose of experiment 2 was to investigate whether or not priming would be obtained for non-cognate translation pairs in L1-L2 direction across Farsi and English that are languages with two different scripts.

\section{Participants}

Twelve Farsi- English bilingual students whose native and dominant language was Farsi were selected for this study. All the participants were BA students of TESOL at Azad University of Najafabad. They had been in the exposure of Farsi from birth however they had received formal training in English at high school, university, and language institutes .Moreover they had very limited exposure to English in natural setting.

Quick Placement Test, 2001 (a 60-item multiple choice grammar test which was version 1) was used to specify the participants' proficiency level. Based on the performance of the whole number of students on this test, some were selected through normalizing the scores. (Mean and standard deviation of the students' scores were calculated and then those whose scores fall between 1SD above and 1SD below the mean were chosen).

\section{Stimuli and Design}

Thirty non-cognate translation equivalents were used as critical items in this experiment. An attempt was made to ensure that the two members of each pair were a unique translation of each other. The average frequency of English targets was 197.16. The stimuli had a mean concreteness value of 487(on a scale of 100-700). Concreteness values were taken from MRC psycholinguistic database (available on the web at http://www.psy.uwa.edu.au/mrcdatabase/uwa_mrc.htm). Each of the targets were preceded once by a translation prime and the other time by a control prime matched with the translation equivalent primes on length, frequency and concreteness as far as possible. The frequency of Farsi control primes was taken from Bijankhan corpus. Farsi Control primes chosen for abstract targets referred to abstract concepts whereas the ones paired with concrete targets referred to concrete objects. Thirty non-words targets were generated by the ARC Non-word Database (http://www.maccs.mq.edu.au/nwdb/). All the non-words were preceded by unrelated primes. Two presentation lists were constructed so that if a target was paired by its translation equivalent on one list, it was paired with its control prime on the other list and vice versa. No target or prime word was repeated within lists.

\section{Procedure}

Using DMDX software (Forster \& Forster, 2003), the stimuli were presented in the center of a PC screen. Each trial consists of the following sequence: first a forward mask of ten hash marks appeared for 500 msc. This forward mask 
was immediately followed by the prime which was presented for $50 \mathrm{msc}$. Finally, the target word immediately followed the prime and remained on the screen until the participants made a response. The font used for target words was 18 Point Times New Roman. Participants were asked to indicate whether or not the appeared target word was a word by pressing withers a Yes or No button. Each participant went through a trial resembling the main task with12 number of items. After each trial was completed, participants received a feedback regarding speed and accuracy of their performance.

\section{B. Experiment 2-L2-L1 Priming}

The purpose of experiment 2 was to investigate whether or not priming would be obtained for non-cognate translation pairs in L2-L1 direction across Farsi and English that are languages with two different scripts.

\section{Participants}

In this experiment, a second group of Farsi dominant bilinguals were selected in the same way as in experiment 1 from the same pool and tested on two English- Farsi lists.

\section{Stimuli and Design}

The lists used for this experiment were simply created by reversing the same Farsi- English lists used in the previous experiment. English control primes used in this experiment were matched with English translation equivalent primes on length, frequency and concreteness. MRC psycholinguistic database was utilized for this purpose. Farsi Non-words targets used for this experiment were generated by changing one or two letters of words matched in length to the targets on that list.

\section{Procedure}

Adopting Forster and Davis (1984) Procedure, presentation of each item in the list included the following masked priming sequence: first, the participant was presented with a row of ten hash marks for 500 ms. this forward mask made participants aware of where the target appears on the screen. Moreover, it masked the subsequently presented prime. Second, the prime word immediately appeared for $50 \mathrm{msc}$. Then a blank interval was presented for $150 \mathrm{msc}$. It consisted of a row of hash marks but was presented in a different font and font size from the forward mask such that two different masks used for each item were quite distinct and different from one another. Finally the target followed immediately after the backward mask. The target remained on the screen until participants made a response. The inclusion of the blank space and the backward mask was for the purpose of increasing the amount of target processing time.

\section{RESUlts}

Scores over $1400 \mathrm{msec}$ and incorrect responses were excluded from analysis. This included 9.5 percent of the data for the first and 4.7percent of the data of the second experiment. All the results are reported at significant level of at least .05. The means of lexical decision times are provided in Table1and 2. Mean response times were 44msec faster for non-cognate translation pairs in the first and $14 \mathrm{msec}$ faster for non-cognate translation pairs in the second experiment. One way ANOVA was performed to test the effect of item type in L1-L2 and L2-L1 directions respectively, F (2,646) = $79.746, p=.000$, and $F(2,683)=60.10, p=.000$. As the tests of homogeneity of variance show inequality of variances in both conditions, a non parametric test (Kruskal-Wallis) was performed on each set of data. The same results were found, X2(2) = 194.067, and X2(2) = 194.062 respectively for L1-L2 as well as L2-L1 direction. Post hoc tests (Sheffee) showed that the non-cognate translation and non-cognate control items were processed the same in both directions; however, nonwords were reacted significantly more slowly than the control and translation equivalents in both directions.

TABLE 1:

DESCRITPIVE STATISTICS OF LEXICAL DECISION TIMES (MS)

Descriptive Statistics

Dependent Variable: reaction time
\begin{tabular}{|ll|c|r|r|}
\hline type & direction & \multicolumn{1}{c|}{ Mean } & Std. Deviation & \multicolumn{1}{c|}{ N } \\
\hline control noncognate & L1-L2 & 851.0818 & 202.24206 & 158 \\
& L2-L1 & 718.5775 & 197.55381 & 167 \\
& Total & 782.9950 & 210.27319 & 325 \\
\hline translation noncognate & L1-L2 & 806.1988 & 173.35554 & 158 \\
& L2-L1 & 704.3654 & 166.76572 & 165 \\
& Total & 754.1786 & 177.24729 & 323 \\
\hline nonword & L1-L2 & 1379.3513 & 753.85740 & 333 \\
& L2-L1 & 1306.1773 & 971.63775 & 354 \\
& Total & 1341.6459 & 873.02872 & 687 \\
\hline Total & L1-L2 & 1111.2085 & 620.07153 & 649 \\
& L2-L1 & 1018.3812 & 768.82759 & 686 \\
& Total & 1063.5085 & 701.74501 & 1335 \\
\hline
\end{tabular}


TABLE 2:

MEAN LEXICAL DECSION TIMES (MS) AND PRIMING EFECTS FOR ENGLISH (L2) TARGETS

\begin{tabular}{|lcc|}
\hline \multicolumn{3}{c|}{ Language order } \\
\hline & Farsi-English & English-Farsi \\
Target & M & M \\
Control & 851.08 & 718.57 \\
Prime & 806.19 & 704.36 \\
Priming effect & 44.89 & 14.21 \\
\hline
\end{tabular}

\section{DISCUSSION AND CONCLUSION}

The main objective of the present study was to investigate whether the priming effect reported in some of the previous studies on non-cognates across languages with different scripts would be repeated across Farsi and English in L1-L2 and L2-L1 direction. As reported before Gollan et.al. (1997), found significant priming effect in L1-L2 direction for both cognates and non-cognates by professional Hebrew-English bilinguals. Gollan et al. (1997) suggested that the change in script between prime and target might have caused this effect as it provides an orthographic cue that enables the prime to be accessed in time to facilitate the recognition of the target; however William (1994) believed that orthographic similarity is not a necessary condition, as he obtained significant non-cognate translation priming with Italian-English, French-English and German- English bilinguals

Contrary to what was found in such experiments, the present study failed to find any priming effect for non-cognates across Farsi and English. This is in accordance with the study of Davis, Sánchez-Casas, \& García-Albea (1991), who observed no priming effect for non-cognates by Spanish-English bilinguals in a lexical decision task under masked paradigm; and García-Albea, Sánchez-Casas and Valero (1996), who confirms the consistent lack of facilitation with non-cognate translations found by Davis et al. (1991) with Spanish-English bilinguals. In both studies, only for cognate translations facilitatory effects were observed only for cognate translations. Lack of significant noncognate priming has also been reported by some other studies (García-Albea, Sánchez-Casas, Bradley, \& Forster, 1985; GarcíaAlbea,Sánchez-Casas,\& Igoa,1998; Grainger \& Frenck-Mestre, 1998).

A possible explanation regarding this phenomenon was advanced by De Groot and Nas, (1991; see also De Groot, 1992). Assuming a model of bilingual memory according to which there are two levels of representation namely a lexical (orthographic-phonological) level and a conceptual (meaning) level, they attributed the effect to the existence of common representations at the conceptual level for cognate translations but not for noncognate translations. This view is also consistent with another model called distributed memory representations (De Groot, 1992). According to this model, cognate translations could share representational nodes or features both at the lexical (form) and at the conceptual (meaning) level, however, noncognate translations might only share features at the conceptual level which is why different experiments fail to obtain significant noncognate priming effect.

Lack of significant effect for noncognates can be interpreted in terms of another hypothesis called "entry opening" (Forster \& Davis 1984; Forster et al., 1987). According to this idea, visual word recognition can be considered as a table look-up procedure. As a stimulus is presented, it would match against a set of stored lexical representation by consulting a table of learned correspondence. First a set of proper lexical candidates are selected according to some abstract representation of the stimuli. As some appropriate matches are found, the corresponding lexical entry opens such that its content becomes available for higher-order language processes. Being opened, it remains in that state for a few seconds in order to allow slower processes to continue access to the lexical database. When the presented stimuli resemble the target word sufficiently to open its entry, some processing time would be saved, as processing of the target would be facilitated based on information stored in that entry. The reason that no facilitation happens for non-cognate translations is that as these translations are listed separately, prime and target open separate entries.

Findings of the present study hold important implication for the dual lexical model proposed by Golan et al. (1997), as it reports different pattern of priming for noncognate translation pairs across Farsi and English, which posses different orthographies. Further, more is known about models such as DRM, which assume weak L2-L1 translation priming. However, definitely more studies needed to be done for both orthographically similar and dissimilar languages in order to provide a clearer picture regarding the role of orthography in non-cognate priming. More studies may present different explanations regarding this issue. 


\section{APPENDIXES}

L1-L2 PRIMING

\begin{tabular}{|c|c|c|c|c|}
\hline Control & Translation & Target/noncog & واسطه & phrewd \\
\hline مربع & ديوار & wall & اسناد & glidge \\
\hline بجִ & آتش & fire & شغلي & knush \\
\hline اقوام & بِيرنده & bird & سني & frult \\
\hline اعطا & تميز & neat & يُزْوهشي & thruiced \\
\hline شب ش ش & خط & line & محله & blooched \\
\hline روشن & بايين & low & حملات & whinxed \\
\hline منحني & قورباغه & frog & موضع & gnoaped \\
\hline استان & هفته & week & سيما & zens \\
\hline فلق & زنغ & bell & شيشه & gwid \\
\hline جوب & دامن & skirt & مشاور & nach \\
\hline واجب & مخلوط & mixture & خطير & maith \\
\hline بهتر & خوب & nice & نوشهر & geald \\
\hline مقاله & جايزه & prize & آن & plir \\
\hline بينز & قصاب & butcher & برنامه & gwux \\
\hline هيجان & حافظه & memory & تجمع & sprugue \\
\hline جֶين & شب & night & ش شديم & rhoiced \\
\hline بِرتخاه & كروهبان & sergeant & بـ & ot \\
\hline همدان & محقق & scholar & 1 & da \\
\hline ش شدن & هيجت & any & معاد & zepes \\
\hline فو لاد & ماهي & fish & اخلاق & tinse \\
\hline الياف & كو سفند & sheep & بيابان & shreethed \\
\hline رئيس & صورت & face & دوردست & shroursed \\
\hline مغازه & روستا & village & مير اث & spafts \\
\hline يا & م & we & ابتدا & scinds \\
\hline نماز & نان & bread & مبتني & smeighths \\
\hline موتور & مسافر & passenger & تضمين & traunched \\
\hline دستخاه & خيابان & street & ورودي & thraived \\
\hline انقلاب & روزنامه & newspaper & حفاظت & phrompts \\
\hline ويزگي & موقعيت & situation & حرم & fafes \\
\hline خالي & عميق & deep & & \\
\hline
\end{tabular}

L2-L1 PRIMING

\begin{tabular}{|c|c|c|c|c|}
\hline Control & Translation & Target/noncog & Apsis & نرواز \\
\hline Pool & wall & ديوار & aster & ثاييد \\
\hline Clay & fire & آتش & apteral & نانا \\
\hline Tail & bird & برِنده & apron & زعنا \\
\hline Calm & neat & تميز & chick & نيره \\
\hline Play & line & خط & chap & خلقه \\
\hline try & low & بإيين & Celt & فنابر \\
\hline Wool & frog & قورباغه & cress & توييدن \\
\hline Told & week & هفته & apprising & فمر اه \\
\hline rice & bell & زنگ & apprises & نوزه \\
\hline Steak & skirt & دامن & charm & فسعت \\
\hline Combine & mixture & مخلوط & chaff & فهت \\
\hline Wise & nice & خوب & yawn & 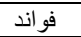 \\
\hline beech & prize & جايزه & yelp & نوجه \\
\hline pianist & butcher & قصناب & apricot & زارا \\
\hline Wisdom & memory & حافظه & approves & نجزيه \\
\hline Point & night & شب ا شب & apprize & مريب \\
\hline Sunlight & sergeant & كرو هبان & aptly & ثهايى \\
\hline Orderly & scholar & محقق & aprons & نبارت \\
\hline Two & any & هيجز & abyss & نر نرايش \\
\hline Gift & fish & ماهي & approach & متابه \\
\hline Fruit & sheep & كو سفند & approver & مر ايط \\
\hline Land & face & صورت & accidence & نختوا \\
\hline Channel & village & روستا & accuser & تونيف \\
\hline so & we & ما & acceptant & آزفون \\
\hline Brick & bread & نان & accent & نكمى \\
\hline physician & passenger & مسافر & accessory & مهارث \\
\hline Ground & street & خيابان & abode & خاض \\
\hline breakfast & newspaper & روزنامه & arbiters & امتلال \\
\hline beginning & situation & موقعيت & arbiter & زهارت \\
\hline grow & deep & عميق & & \\
\hline
\end{tabular}




\section{REFERENCES}

[1] Bowers, J. S., Mimouni, Z., \& Arguin, M. (2000). Orthography plays a critical role in cognate priming: Evidence from French/English and Arabic/French cognates. Memory \& Cognition, 28, 1289-1296.

[2] Chen, H.-C., \& Ng, M.-L. (1989). Semantic facilitation and translation priming effects in Chinese-English bilinguals. Memory \& Cognition, 17, 454-462.

[3] Cristoffanini, P., Kirsner, K., \& Milech, D. (1986). Bilingual lexical representation: The status of Spanish-English cognates. Quarterly Journal of Experimental Psychology, 38A, 367-393.

[4] Davis, C.W., Sánchez-Casas, R.M.y García-Albea, J.E. (1991). Bilingual Lexical Representation as revealed using de masked priming procedure, Manuscrito no publicado. ST. Louis University( Madrid campus).

[5] de Groot, A. M., \& Nas, G. L. (1991). Lexical representation of cognates and noncognates in compound bilinguals. Journal of Memory \& Language, 30(1), 90-123.

[6] de Groot, A. M. B. (1992). Determinants of Word Translation. Journal of Experimental Psychology: Learning Memory and Cognition, 18, 1001-1018.

[7] Evett, L. J., \& Humphreys, G. W. (1981). The use of abstract graphemic information in lexical access. Quarterly Journal of Experimental Psychology, 33A, 325-350.

[8] Forster, K.I., \& Davis, C. (1984). Repetition priming and frequency attenuation in lexical access. Journal of Experimental Psychology: Learning, Memory, and Cognition, 10, 680-698.

[9] Forster, K.I., Davis, C., Schoknecht, C., \& Carter, R. (1987). Masked priming with graphemically related forms: Repetition or partial activation? Quarterly Journal of Experimental Psychology, 39, 211-251.

[10] Forster, K. I., \& Forster, J. C. (2003). DMDX: A Windows display program with millisecond accuracy. Behavior Research Methods, Instruments, \& Computers, 35, 116-124.

[11] García-Albea, J.E., Sánchez-Casas, R. Bradley, D.C. \& Forster, K.I. (1985). Cross-language priming effects in bilingual word recognition. Paper presented at the Fifth Australian Language Conference. Melbourne. November.

[12] García-Albea, J.E., Sánchez-Casas, R.M., \& Igoa, J.M. (1998). The contribution of word form and meaning to language processing in Spanish: Some evidence from monolingual and bilingual studies. In D. Hillert (Ed.), Sentence Processing: A cross-linguistic perspective (pp. 183-209). New York: Academic Press.

[13] García-Albea, J.E., Sánchez-Casas, R. \& Valero, T. (1996). Form and meaning contribution to word recognition in CatalanSpanish bilinguals. Paper presented at the Ninth Conference of the European Society for Cognitive Psychology, University of Würzburg, September.

[14] Gollan, T., Forster, K. I., \& Frost, R. (1997). Translation priming with different scripts: Masked priming with cognates and noncognates in Hebrew-English bilinguals. Journal of Experimental Psychology: Learning, Memory, and Cognition, 23, 11221139 .

[15] Grainger, J., \& Frenck-Mestre, C. (1998). Masked priming by translation equivalents in proficient bilinguals. Language \& Cognitive Processes, 13, 601-623.

[16] Keatley, C. \& de Gelder, B. (1992). The bilingual primed lexical decision task: Crosslanguage priming disappears with speeded responses. European Journal of Cognitive Psychology, 4, 273-292.

[17] Keatley, C. W., Spinks, J. A., \& de Gelder, B. (1994). Asymmetrical cross-language priming effects. Memory \& Cognition, 22, $70-84$.

[18] Kirsner, K., Smith, M. C., Lockhart, R. S., King, M. L., \& Jain, M. (1984). The bilingual lexicon: Language-specific units in an integrated network. Journal of Verbal Learning and Verbal Behavior, 23, 519-539.

[19] Kroll, J. F., \& Curley, J. (1988). Lexical memory in novice bilinguals: The role of concepts in retrieving second language words. In M. Gruneberg, P. Morris, \& R.Sykes (Eds.), Practical aspects of memory (Vol. 2, pp. 389-395). London: Wiley.

[20] Kroll, J. F., and Stewart, E. (1994). Category interference in translation and picture naming: Evidence for asymmetric connections between bilingual memory representations. Journal of Memory and Language, 33, $149-174$.

[21] MacLeod, C. M. (1976). Bilingual episodic memory: Acquisition and forgetting. Journal of Verbal Learning and Verbal Behavior, 15, 347-364.

[22] OUP (2001). Quick Placement Test: Paper and Pen Test, User Manual. Oxford University Press.

[23] Potter, M.C., So, K.-F., Von Eckardt, B., \& Feldman, L.B. (1984). Lexical and conceptual representations in beginning and more proficient bilinguals. Journal of Verbal Learning and Verbal Behavior, 23, 23-38.

[24] Sanchez-Casas, R. M., Davis, C. W., \& Garcia-Albea, J. E. (1992). Bilingual lexical processing: Exploring the cognate/noncognate distinction. European Journal of Cognitive Psychology Special Issue: Multilingual community, 4(4), 293-310.

[25] Smith, M. C. (1991). On the recruitment of semantic information for word fragment completion: Evidence from bilingual priming. Journal of Experimental Psychology: Learning, Memory, and Cognition, 17, 234-244.

[26] Schwanenflugel, P. J., \& Rey, M. (1986). Interlingual semantic facilitation: Evidence for a common representational system in the bilingual lexicon. Journal of Memory \& Language, 25, 605-618.

[27] Weinreich, U. (1953). Languages in contact: Findings and problems. New York: Linguistic Circle of New York.

[28] Williams, J.N. (1994). The relationship between word meanings in the first and second language: Evidence for a common, but restricted, semantic code. European Journal of Cognitive Psychology, 6, 195-220.

[29] http://www.psy.uwa.edu.au/mrcdatabase/uwa_mrc.htm. MRC psycholinguistic database.(accessed 29/10/2010).

[30] http://ece.ut.ac.ir/dbrg/bijankhan. Bijankhan Corpus.2010.(accessed 15/9/2010).

[31] http://www.maccs.mq.edu.au/nwdb/. ARC Non-word Database. (accessed 25/10/2010).

Zahra Fotovatnia is Assistant Professor of AL at Islamic Azad University, Najafabad Branch, Iran. She has attended the $2^{\text {nd }}$ Linguistics Conference, Greece; EuroSLA17, UK; Asia TEFL, Malaysia; $8{ }^{\text {th }}$ IECP, Spain; and ICP2004 Beijing. She has published 
articles in a Journal of Shiraz University, Language Forum, and Pajjohesh in Educational Sciences. Her area of interest includes pedagogical phonetics and phonology and psycholinguistics.

Ferdos Taleb is an M.A. student of TESOL at Islamic Azad University, Najafabad Branch, Iran. 